Фельденкрайз, 2010 - Фельденкрайз М. Осознавание через движение: двенадцать практических уроков /М. Фельденкрайз.- СПб.: Ин-т общегуманит.исслед., 2010. - 236 с.

Хорни, 2004 - Хорни К. Невротическая личность нашего времени. Самоанализ / К. Хорни. М. : Айрис - пресс, 2004. - 607 с.

Ялом, 1999 - Ялом И. Экзистенциальная психотерапия /И. Ялом. - М. : Класс, 1999.- 312 с.

\title{
REFERENCES
}

Aleksander, 2002 - Aleksander F. Psykhosomatycheskaia medytsyna. Pryntsypy y prymenenye / F. Aleksander / Per. s anhl. S. Mohylevskoho. - M. : Yzd-vo EKSMO-Press, 2002. - 352 s. (Seryia «Psykholohyia bez hranyts»).

Yzard, 1999 - Yzard Kerrol E. Psykholohyia emotsyi / K. Yzard. - Per. s anhl. - SPb. : Pyter, 1999.$464 \mathrm{~s}$.

Louen, 2000 - Louen A. Psykholohyia tela. Byoenerhetycheskyi analyz tela / Aleksandr Louen // Elektronnyi resurs / Rezhym dostupa: www.litmir.me.

Osypova, 2005 - Osypova A. A. Spravochnyk psykholoha po rabote v kryzysnыkh sytuatsyiakh / A. A. Osypova. - R/nD. : Fenyks, 2005. - 315 s.

Patterson, Uotkyns, 2003 - Patterson S., Uotkyns E. Teoryy psykhoterapyy. - 5-e yzd. - SPb. : Pyter, 2003. $-762 \mathrm{~s}$.

Raikh, 2000 - Raikh V. Analyzlychnosty / V. Raikh / Per. s anhl. E. Pole. - M. : AprelPress, Yzd-vo EKSMO-Press, 2000. - $528 \mathrm{~s}$.

Rean, 2002 - Rean A. A. Psykholohyia cheloveka ot rozhdenyia do smerty / A. A. Rean. - SPb., 2002. 656 s. - («Psykholohycheskaia entsyklopedyia»).

Khomych, 2016 - Khomych H. O. Osobystist v umovakh sotsialnoi depryvatsii / H. O. Khomych // Rozvytok osobystosti $\mathrm{v}$ riznykh umovakh sotsializatsii: kolektyvna monohrafiia/Za red.

L. O. Kalmykovoi, H. O. Khomych.- K. : Vydavnychyi dim «Slovo», 2016. - S. 334-348.

Ruppert, 2014 - Ruppert F. Travma, sviaz y semeinye rasstanovky. Poniat y ystselyt dushevnыe rany /Frants Ruppert.- M. : Ynstytut konsultyrovanyia y systemnykh reshenyi, 2014.- $264 \mathrm{~s}$.

Feldenkraiz, 2010 - Feldenkraiz M. Osoznavanye cherez dvyzhenye: dvenadtsat praktycheskykh urokov / M. Feldenkraiz.-SPb.: Yn-t obshchehumanyt. yssled., 2010. - 236 s.

Khorny, 2004 - Khorny K. Nevrotycheskaia lychnost nasheho vremeny. Samoanalyz / K. Khorny. M. : Airys - press, 2004. - $607 \mathrm{~s}$.

Yalom, 1999 - Yalom Y. Ekzystentsyalnaia psykhoterapyia /Y. Yalom. - M. : Klass, 1999.- 312 s.

УДК 159.944.4:355.08

\section{Світлана Герасіна}

\section{ОСОБЛИВОСТІ ПРОЯВУ ПОСТТРАВМАТИЧНИХ СТРЕСОВИХ РОЗЛАДІВ В УЧАСНИКІВ АТО}

У статті теоретично обтрунтовано проблему впливу психотравмуючих подій, пов'язаних з військовим конфліктом на сході Украӥни, на психоемоційний стан бійців - учасників антитерористичної операції (АТО). Проаналізовано сучасні наукові дослідження з питань взаємозв'язку бойового стресу з посттравматичними емоційними розладами, які спричиняють інтрузії (психотравматичні спогади i переживання, флеш-беки, моторошні сновидіння); уникання (розмов, місць, звуків, запахів тощзо), щуо нагадують травматичну подію; гіперактивність, яка виявляється в ажитації, інтенсивному емоційному $i$ фізіологічному збудженні та в непродуктивній психомоториці. Доведено доцільність застосування психодіагностичної методики «Міссісіпська шкала» (військовий варіант) у вивченні симптомокомплексів: «інтрузій» - емочійне застрягання; «уникання» - витіснення травматичних спогадів; «гіперзбудження» - гіпертрофована психофізіологічна реакція; почуття провини й сорому та суйидальних схильностей. Визначено стресогенні фактори деструктивного впливу на психологічне здоров'я бійців: надмірну відповідальність, небезпеку, 


\section{Psychology}

загибель товаришів, поранення, контузї̈, тривале перебування в АТО. Запропоновано основні психотерапевтичні стратегії психореабілітації учасників АТО.

Ключові слова: учасник антитерористичної операції (АТО), бойовий стрес, психотравматизація, посттравматичний стресовий розлад (ПТСР), інтрузї, емоційне заціпеніння, гіперактивність, дезадаптація.

The article represents theoretical substantiation of the problem of the impact connected with traumatic events related to the military conflict in the east of Ukraine, on the psycho-emotional state of the soldiers participating in the antiterrorist operation (ATO). There is analysis of modern scientific researches on the interdependence of combat stress with post-traumatic emotional frustration of fighters, causing: intrusive memories, flashbacks and sleep disturbances; avoidance, manifested in emotional distress, apathy, indifference, despair, depression; hyperactivation, which manifests itself in agitation, intense emotional and physiological excitement, and in unproductive psychomotorism. There is proving of the expediency of psychodiagnostic method "Mississippi Scale» (military option) in the study of symptom complexes: «intrusions»-emotional jostling; «Avoidance» - suppression of traumatic memories; "hypersensitivity» - hypertrophied psychophysiological reactions; feelings of guilt and shame and suicidal inclinations. There is empirical definition of psychological peculiarities of respondents with post-traumatic stress disorder as a kind of neurosis, manifested as a result of the simultaneous experience of several psychotraumatic events by a fighter. There is disclosure of PTSD as a delayed reaction of the individual to a stressful event of a threatening nature, which also caused chronic stress - distress. The psychopathological condition of fighters is revealed, which is caused by the necessity to perform responsible combat tasks under the conditions of extreme ATO factors. There is determination of destructive mental states that are developing in the military and in the period of adaptation to the usual conditions of life and service, after returning from the war that reduces the stress resistance and the process of social adaptation.There is description of stressful factors: high responsibility, danger, death of friends, injury, contusion, disability, long stay in the ATO, etc., which destructively affect the psychological health of the soldiers. The basic psychotherapeutic strategies of psychoanalysis of ATO participants are offered: updating of adaptive skills and renewal of own resources of «I»; formation of "positive attitude» to the symptom; reduction of avoidance, focus on the transformation of psychotraumatic experience; change in the attribution of the content of the traumatic situation and its consequences, the feeling of its own "control and authority over the psychotrauma».

Keywords: participant of antiterrorist operation (ATO), combat stress, psychotraumatisation, post-traumatic stress disorder (PTSD), intrusions, emotional numbness, hyperactivation, disadaptation.

Постановка проблеми. Військовий конфлікт на сході України $€$ психотравмуючим фактором інтенсивного впливу на психоемоційне здоров'я людей. До антитерористичної операції (АТО) причетні люди різних категорій, віку і професій, серед яких значна частина людей без належної військової підготовки. Численні дослідження свідчать, що тривале перебування в зоні бойових дій (більше 50 діб) спричиняє виснажливе психічне напруження та посттравматичні стресові розлади, які деструктивно впливають на психоемоційний стан людини і діють не прогнозовано. Особливого значення у життедіяльності військовослужбовців набуває бойовий стрес та його психологопсихіатричні наслідки.

Участь у бойових діях пов'язана 3 морально-психологічним ціннісним аспектом, патріотизмом, виконанням обов'язків,разом 3 тим, війна $\epsilon$ одним із найсуворіших особистісних випробувань, перевіркою психологічних i фізичних можливостей бійця. Кожна людина надто вразлива перед потужними стрес-факторами війни (висока відповідальність, небезпека, загибель товаришів, поранення, інвалідність, 
біль, участь у жорстокому насильстві, знищення супротивника, непередбаченість подій тощо).

Серед провідних причин постійної психотравматизації виділяють: змушеність бійців діяти всупереч природному інстинкту самозбереження, ігноруючи власні потреби, що актуалізує депривацію; усвідомлення бійцями факту непередбачуваності бойового стресу щодо часу, локалізації, інтенсивності впливу, частоти повторювань, тривалості дії та ступеня екстремальності, така багатократність і випадковість детермінується постійною загрозою смерті.

Отже, водночас із бойовим досвідом учасники АТО отримують психічні і фізичні травми, а їхня психіка зазнає значних змін (порушень, хронічних хвороб, деформацій тощо). Стрес, пережитий людиною в екстремальних ситуаціях, як правило, за своєю інтенсивністю виходить за межі звичайного людського досвіду, що часто призводить до формування різних психічних розладів.

Так, учені О. Доморацький, П. Волошин, А. Столяренко, Н. Тарабріна, Л. Шестопалова, О. Чабанзазначають, що майже у 30\% осіб, які пережили психотравмуючу подію, розвивається стан, що увійшов у психіатричну практику як посттравматичний стресовий розлад (ПТСР). Він $\epsilon$ одним із найбільш поширених розладів - щонайменше $7 \%$ осіб (5\% чоловіків, 10\% жінок) переживає ПТСР упродовж життя. Із них у близько $30 \%$ осіб перебіг розладу набуває хронічного характеру 3 можливою персистенцією, тобто інкубацією та можливим рецидивом симптомів на 10 і більше років життя.

Однак, посттравматичні емоційні реакції індивіда є одним із видів розладів, пов'язаних 3 психотравмуючими подіями [Близнюк, 2015; Волошин, Марута, Шестопалова, 2014; Чабан, 2016].

Отже, вчасна діагностика, кваліфікована профілактика та терапія тяжких психоемоційних переживань $є$ важливою й актуальною проблемою сучасної прикладної психології. Тому теоретико-емпіричне вивчення особливостей прояву посттравматичних стресових реакцій в умовах бойових дій є нагальним запитом сьогодення вітчизняної науки.

Аналіз останніх досліджень і публікацій. До вирішення проблеми впливу бойового стресу на психоемоційний стан військовослужбовців звертається багато українських учених: А. Грись, О. Кокун, О. Штепа вивчають механізми активізації адаптаційних можливостей воїна; В. Крайнюк, Г. Пилягіна - підвищення стресостійкості особистості в екстремальних умовах; Ю. Бучок, М. Мушкевич, Л. Підлисецька симптоми прояву та психокорекційні методи ПТСР у військовослужбовців; М.Бялая, Л.Гридковець, О.Чабан - психосоматичні розлади військовослужбовців; Н. Комарова, О. Новак, А. Мельник, Г. Хомич надання психологічної допомоги учасникам АТО та їхнім сім'ям. 


\section{Psychology}

Однак, недостатня увага звертається на теоретико-емпіричне вивчення специфіки емоційного стану особистості 3 психотравмованим досвідом та його впливу на подальшу іiї життєдіяльність.

Серед вітчизняних і зарубіжних дослідників питання, що пов'язані 3 різними аспектами психодіагностичної та психотерапевтичної допомоги військовослужбовцям, розглядали:американський психолог Дж. Ялом спеціаліст IPT-та MBSR-тренер (Швейцарія); О. Кірюхіна, О. Акімов, О. Чабан вивчали наслідки бойових психічних травм під час війн; А. Бравєє, В. Гічун, В. Ковтун, О. Коржиков, Ю. Лях аналізували медикосоціальні аспекти реабілітації військовослужбовців; В. Коханов, В. Краснов, І. Малкіна-Пих, Н. Тарабріна глибинно теоретизували психологію посттравматичного стресу; Н. Марута, Л. Шестопалова досліджували розлади адаптації (діагностика, лікування, реабілітація); В. Березовець, С. Захарик, В. Знаков, І. Ліпатов, В. Попов, П. Сідоров, В. Стасюк досліджували наслідки бойових психічних травм; Д. Сапон, О. Друзь, А. Кожина, Б. Михайлов (Інститут неврологіï, психіатрії i наркології НАМН України) вивчають психоемоційний стан учасників АТО у медичному контексті.

Мета i завдання статmі полягає у теоретико-емпіричному вивченні особливостей переживання психоемоційних стресових розладівбійцями, які зазнали травматизації, перебуваючи в зоні військового конфлікту на сході України; визначенні основних стресфакторів, що спричиняють психотравматизацію бійців; окресленні напрямів психотерапевтичного супроводу учасників АТО.

Виклад основного матеріалу. Аналіз теоретикоекспериментальних досліджень виявив, що одним із провідних психоемоційних порушень учасників бойових дій $\epsilon$ посттравматичні стресові реакції (ПТСР). За різними даними подібний психоемоційний станперебуває на 2-3 місці [Герасіна, Гуріна, 2017: с. 98; Гріненко, Матяи, Чабан, 2016; Підлисецька, 2014].

Вивченням перебігу і механізмів ПТСР - головного психологічного наслідку участі в бойових діях - ще у XIX-XX ст. займалися в основному клініцисти Дж. Еріксен (1866), Г. Оппенгейм (1888), Е. Штирлінг (1909, 1911), Е. Крепелін (1916). Активно проблему ПТСР вивчав професор, директор психіатричної клініки Мюнстерлінгена (Швейцарія) Герхард Дамманн зі своєю командою. Згодом, до вирішення цих проблем долучилися і психологи [Пілягіна, 2016].

Однак, результати аналізу наукових джерел свідчать про те, що вітчизняною наукою ще недостатньо вивчено психологічні аспекти процесу перебування особистості в зоні бойових дій. Спектр можливих психічних розладів, пов'язаних 3 переживанням життєво небезпечних ситуацій, містить гостру реакцію на стрес, ПТСР, розлади адаптації, гострі i транзиторні психотичні порушення, депресивні i тривожні розлади, інтрузивні стани, хронічні зміни особистості тощо [Близнюк, 2015]. 
Доцільно акцентувати увагу на клінічних діагностичних критеріях ПТСР, які умовнокласифікуютьсяна чотири основні види (критеріï): А, В, C, D [Підлисецька, 2014].

Критерій А - «травматична подія»: людина перебуває під впливом екстремально напруженої події, пов'язаної із загибеллю або пораненням, i в момент знаходження у травматичній ситуації відчуває інтенсивний страх, моторошне самопочуття і безпорадність.

Критерій В - «травматичне вторгнення»-інтрузії: травматична подія нав'язливо повторюється у переживаннях людини у вигляді відповідних спогадів, образів, думок і почуттів, які спричиняють важкі емоційні стани, жахливі сновидіння; а також «флеш-бек» ефекти моментальне, без видимих причин, відтворення 3 патологічною достовірністю і повнотою відчуттів травматичної ситуації у поєднанні 3 гострими спалахами страху, паніки або агресії, відчуття, що травматична подія знову відбувається. Можливі прояви фізіологічної вегетативної гіперактивності в ситуаціях, які зовні чи внутрішньо сигналізують про травматичну подію.

Критерій C - «уникнення», що має ознаки блокування емоційних реакцій, емоційне заціпеніння/оніміння: людина намагається уникати думок, почуттів або розмов, пов'язаних із травмою, помітно знижується інтерес до життя, проявляється апатія, часткова психогенна амнезія нездатність згадати важливі аспекти травми. Актуалізується психологічний механізм захисту, що витісняє психотравмуючі маркери зі свідомості людини.

Критерій D - «гіперактивація»/«ажитація» - інтенсивний емоційний імпульс, що провокує фізіологічне збудження, яке супроводжується непродуктивною моторною активністю. Подібний стан спричиняєпорушення сну,некеровані спалахи дратівливості та гніву, труднощі із зосередженням уваги, підвищену настороженість і підозрілість, стан постійного очікування загрози, що детермінує патерн поведінки - стан «бойової готовності».

У сучасній психотерапії i психокорекції ПТСР домінує інтегративний підхід. У всіх реабілітаційних заходах необхідна апеляція до особистості потерпілих, оскільки при інтенсивному впливі травматичного стресу страждає насамперед особистість. ПТСР, за своєю глибинною сутністю, є взаємодією особистості з пережитим стресовим досвідом, при цьому феноменологія тих чи інших психічних порушень, що виникають внаслідок переживання екстремальної події, певною мірою відображає якість стресової адаптації особистості, тобто ії копінг-поведінкові стратегії.

Згідно армійських стандартів високо розвинутих країн, особовий склад Збройних Сил країни потребує кваліфікованого психологічного супроводу та реабілітації, особливо після перебування в екстремальних умовах, перш ніж повернутися в сім'ю. Проте в українській армії ці стандарти в повному обсязі не виконуються, а необхідність у психологах 


\section{Psychology}

нівелюється. У сучасних критичних умовах особливо не вистачає військових i кризових психологів, а також травматерапевтів. Діюча Асоціація налічує близько 500 спеціалістів, але тих, хто працює у зоні АТО значно менше. Людина, яка перебуває в умовах бойових дій, безумовно зазнає стресу,тому є необхідність у періодичній ротації як бійців, так i психологів (військових, кризових, капеланів тощо) [Агаєв, Кокун, Остапчук, 2015].

Така ситуація вимагає кваліфікованої діагностики психоемоційного стану учасників бойових дій. Об'єктивна діагностика вимагає підбору валідного інструментарію, який би мав експрес-націленість, оскільки будьякі бойові дії є ризикованими для життя. У ході діагностики необхідно враховувати 2 основних чинники, від яких залежить інтенсивність переживання стресу бійцями:специфіку дії/впливу на психіку людини різнопланових стресорів (сила, тривалість, частота тощо); індивідуальне психоемоційне реагування на стресогенні фактори (спектр змінних, що визначають ті чи інші реакції,стан, поведінку в бою та ін.). Завчасна діагностика психічних станів і виявлення суб'єктів групи ризику, які потребують посиленої психологічної уваги, дозволяє на ранніх етапах виявити бійців 3 низьким адаптаційним потенціалом, унаслідок зміни психоемоційного стану, а також ранніми проявами психотравматизації та іiі наслідків.

Директор Українського державного медико-соціального центру ветеранів війни Ю. Гріненко, висвітлюючи досвід психореабілітації учасників АТО, подає таку градацію їхньої захворюваності:

1. психічні розлади, обумовлені ушкодженням i дисфункцією головного мозку $-33 \%$.

2. посттравматичні стресові розлади $-18 \%$.

3. психічні порушення: легка розумова відсталість, неврастенія, депресивні епізоди та тривожно-депресивні стани $-17,8 \%$.

4. адаптаційні розлади - $12 \%$ [Гріненко, 2016].

Вказані дані деякою мірою відображають реальну ситуацію і нашого теоретико-емпіричного дослідження.

Моніторинг динамічних і статичних показників психоемоційного стану учасників бойових дійпередбачав систематичне фіксування та прогнозування критичних відхилень симптомокомплексів 3 метою екстреного відреагування та застосування корекційнихвпливів.

Кваліфікована діагностика психоемоційної сфери бійця дає змогувчасно: здійснити інтервенції з метою виявлення і корекції на ранній стадії інтрузивних спогадів та переживань; запобігти й зменшити рівень прояву психічних розладів і захворювань; розробити і впровадити тактику індивідуальної/групової психотерапії, реабілітації чи профілактики в умовах лікувально-рекреаційного відновлення учасників АТО. Зазначені заходи сприятимуть більш ефективному використаннюлюдського ресурсу та військового потенціалу, активізують стресостійкість,раціональний 
ризик, якісневиконання бойових завданьта адаптаційні навики бійців в екстремальних і непередбачуваних умовах.

Експериментальне дослідження здійснювалося на базі Головного військового клінічного госпіталю (м.Київ), Військового шпиталю (м. Ірпінь, Київська область) та рекреаційно-оздоровчого центру (м. Хирів, Львівська область). До психодіагностичного дослідження було залучено 74 учасники бойових дій, які перебували(у різні терміни таз різною тривалістю)в зоні АТО на сході України [Герасіна, Гуріна, 2017: с. 94].

Емпіричне вивченнярівня прояву посттравматичних стресових реакцій бійців учасників АТО, здійснювалося за методикою «Міссісіпська шкала ПТСР». За основу було взятоклінічну тестову методику «Mississippi Scale», розроблену англійськими вченими Т. Кін, Дж. Кадделл, К. Тейлор у 1988 році.Вітчизняний аналог, зокрема військовий варіант, був адаптований і модифікований Н. Тарабріною для діагностики ПТСР в осіб, які зазнали психічної травматизації, перебуваючи в екстремальних умовах [Тарабріна, 2009; Агаєв, 2016].

Міссісіпська шкала (військовий варіант)містить 35 запитань, які визначають 3 групи симптомів ПТСР згідно DSM-III,утворюючи 3 основні шкали:1-ша шкала (11 запитань)описує симптомокомплекс критерію «інтрузії» (травматичні переживання, флеш-беки); 2-га шкала (11 запитань) - симптомокомплекс критерію «уникнення» (витіснення травматичних спогадів); 3-тя шкала (8 запитань) - симптомокомплекскритерію «Гіперзбудливість» (некерована гіперактивність, ажитація, гіпертрофовані психофізіологічні реакції); решта 5 запитань описують симптомокомплекс, пов'язаний 3 почуттям провини та суїцидальними нахилами. Експериментальні дослідження показали високу внутрішню узгодженість військового $(0,94)$ і цивільного $(0,86)$ варіантів шкали. Міссісіпська шкала не рекомендована для первинного скринінгового виявлення ПТСР, першочергова ціль - підтвердженнятаоцінка ступеня тяжкості ПТСР.

Тому методика використовується у діяльності психологів спецслужб, силових відомств, у роботі з особами, які зазнають екстремальних психологічних навантажень (військовий, рятувальник, поліцейський охоронець, журналіст та ін.). Однак, слід диференціювати ПТСР від патологічних особистісних реакцій, декомпенсації неврозів, дебюту афективних і ендогенних процесів тощо.

Отже,методика «Міссісіпська шкала ПТСР»призначена для визначення ступеня вираженості посттравматичних стресових реакцій в учасників бойових дій. Узагальнений показник дозволяе виявити специфіку впливу травматичного досвіду на психоемоційний станіндивіда.Методика є одним із широко застосовуваних інструментів для вимірювання ознак ПТСР.

Аналітичне вивченняемпіричного матеріалу засвідчило, щозначній частині бійців (81\%) притаманнийнормальний рівень адаптації,що $\epsilon$ позитивною детермінантою соціальної адаптації. Численні дослідження 


\section{Psychology}

вказують, що саме адаптаційні розлади є основною проблемою бійців, які повернулися до мирного життя [Герасіна, Гуріна, 2017: c.94; Гріненко, Грись, 2016].

У $16 \%$ респондентів виявлено психічні розлади, що свідчить про наявність стійких психопатологічних станів, які характеризуються порушеннями психічної діяльності та здатності повноцінно функціонувати, що призводить до страждань, низької стресостійкості та деструктивної соціальної адаптації.

Зауважимо, що посттравматичний стресовий розлад виявлено у незначної кількості учасників бойових дій $(8 \%)$. Виявленийпсихічний розлад, як різновид неврозу, проявився у бійців у результаті переживання одночасно кількох психотравматичних подій. $\mathrm{y}$ декого 3 респондентіввиник як відстрочена реакція (латентний період до 6 місяців) на стресову подію загрозливого характеру, щой спричинило хронічний стрес - дистрес. Необхідно відзначити, що у більшостібійців розвиток психопатологічних станів пов'язаний 3 психічною травматизацією в процесі виконання бойових завдань в АТО та при дії екстремальних факторів. Водночас, деструктивні психічні стани розвиваються у військовослужбовців і в період реадаптації до звичайних умов служби, після повернення з війни, що знижує стресостійкість та процес соціальної адаптації.

Узагальнені результати діагностування, інтерпретація бесід та спостереження за психоемоційними патернами поведінки бійців дали змогу виявити фактори, які беззаперечно впливають на специфіку прояву ПТСР, зокрема термін перебування у зоні АТО, поранення різного ступеня, контузії та втрата побратимів.

Підкреслимо, що тривале перебуванняіндивіда в зоні бойових дій критичновідображається як на фізичному, так i на психологічному здоров'ї, що спричиняє розлади адаптивних навиків та копінг-поведінки суб'єкта. Ученізазначають, що здатність особистості долати стрес є значно важливішою, аніж генезис,потужність та частота впливу стресу на людину [Волошин, Заворотний, 2015; Близнюк, 2015; Тарабріна, 2009]. Оскільки копінг-поведінка базується наактивізації когнітивних, моральних, соціальних і мотиваційних конструктів особистості у процесі подолання проблеми. У разі нездатності суб'єкта адекватноопановувати себе включаються захисні механізми, які спричиняють пасивність чи уникнення. Такі механізми $є$ ригідними, дезадаптивними способами реагування на проблеми, що перешкоджають адекватній орієнтації індивіда у реальній дійсності.

Результати аналізу наукових джерел свідчать про те, що вітчизняною наукою ще недостатньо вивчено психологічні аспекти процесу перебування особистості в зоні бойових дій. До того ж, відсутні державні наукові програми, які були б присвячені дослідженню проблем 
військовослужбовців - учасників бойових дій у районах військових конфліктів на сході України [Владимиров, Грінено, 2016; Попіль, 2016].

Термін перебування бійціву зоні АТО становив від 1-го до 36-ти місяців. Значна частина бійців $(75 \%)$ у зоні військового конфлікту перебуваливід 6 до 24 місяців, що свідчить про довготривалість впливу бойового стресу на психоемоційний стан воїнів, які залучені до емпіричного дослідження.

Для того, щоб вижити у бойовій обстановці, людина повинна максимально налаштуватися на неї, ресурсно мобілізувати психофізичні ресурси (рівень пильності i активності, швидкість реакцій, стиль поведінки, систему цінностей і ставлення до навколишнього, людей, себе тощо), відповідно до вимог обстановки. Така перебудова, пристосування до режиму бойової життєдіяльності, до стрес-факторів війни, що відбувається 3 кожним іiі учасником, називається «бойовим стресом». Отже,під бойовим стресом розуміємо багатоступеневий процес адаптаційної активності людського організму в умовах бойової обстановки, що супроводжується напруженістю механізмів реактивної саморегуляції та закріпленням специфічних психофізіологічних змін пристосувального характеру. Водночас, бойовий стрес є сукупністю суб'єктивнихстанів, пережитих бійцями у процесі адаптації до несприятливих, життєзагрожуючих умов бойової обстановки. Інтенсивність переживання бойового стресу залежить від взаємодії 2основних чинників: сили i тривалості впливу на психіку бойових стрес-факторів; специфіки індивідуального реагування та способів подоланняпроблемної ситуації (копінг-поведінка).

Наступним важливим фактором є поранення бійців, які перебували у зоні військового конфлікту. Виявлено, що $23,2 \%$ бійців отримали поранення і травми різного ступеня тяжкості, анатомічні і функціональні порушення, що виникли внаслідок поранень та негативно впливають на боєздатність (навіть унеможливлюють іiі). Такий стан потребує тривалогой багатоетапного лікування, що $\epsilon$ серйозною перешкодою соціальної адаптації.

Емпірично було виявлено, що $33,9 \%$ бійців зазнали контузій, які спричиняють швидку i затяжну стомлюваність, погане самопочуття, підвищену дратівливість тощо. Подібний станбійців підвищує рівень впливу стресових факторів, знижує боєздатність або ж повністю виводять їх зі строю, внаслідок чого постраждалі потребують тривалого лікування, повного спокою і температурного режиму (уникати перегрівань).

Дослідники пишуть, що ні з чим не порівняти психоемоційний стрес, що зазнає боєць, якому довелося спілкуватися з тяжко пораненими, пережити загибель побратимів (бачити тіла загиблих, їх торкатися) та змиритися з необхідністю вбивати інших [Агаєв, 2016]. Людина, яка стала свідком смерті своїх товаришів, неодмінно переживатиме почуття провини при відсутності на те об'єктивних причин. 


\section{$\frac{\text { Psychology }}{3 a 3+24}$}

Зазначимо, що почуття провини й сорому у більшості бійців $\epsilon$ нормальною регулятивною функцією їхньоїповедінки, однак пекуче i тривале почуття провини спричиняє деструктивні явища: самозвинувачення, самокатування, відчуття «нікчемності», що потребує психологічної корекції чи терапії. У ході взаємодії з такими бійцями були помічені прояви неусвідомлюваних механізмів (супроводів) свідомих дій: ригідні переконання, упереджене ставлення, негативна установка, неконтрольована агресія тощо. До того ж, таким людям вдавалося контролювати свої зовнішні дії (слова, рухи) і набагато важче - м'язовий тонус (позу, міміку, пантоміміку, інтонацію).

Дослідження українського вченого у галузі психіатрії та медичної психології О. Чабана підтверджують факт наявності почуття вини і сорому в учасників бойових дій. Так, почуття вини психіатр диференціює на особистісне, вибіркове та локальне [Чабан, 2016]. У ході психотерапевтичної взаємодії з респондентамипідтверджено,що домінує вибірковий тип провини, тобто докори сумління 3 приводу певних ситуацій, що не дають спокою, висловлення мали екзистенційне спрямування, оскільки стосувалися глибинного осмислення безпечності й благополуччя власної життєдіяльності, своєї родини та українських громадян загалом. Почуття провини поєднує страх, аутоагресію і систему психологічних захистів від внутрішньої агресії.

Психодіагностична взаємодія засвідчила той факт, що учасники бойових дій діляться як песимістичними, так і оптимістичними спогадами. Дехто з них неодноразово розповідає історії, які $є$ психотравмуючими для них, однаку них яскраво виражена потреба ділитисяними знову і знову (i не тільки з психологом), що свідчить про певне психологічне застрягання (зациклення). Тобто людина сповна ще не прожила ситуації, чергова оповідь розгортає нову палітру полярних емоцій і почуттів, які вона поновому проживає. Такий психоемоційний стан проявляється у збудженні, впертості, нетерпимості до заперечень тощо. Поведінка такої категорії бійцівєнестримною, безпідставно суперечливою, спостерігається схильність до заперечень очевидного.

Отже, людина перебуває в стані афективної стагнації, зациклена на однотипних думках і почуттях, особливо коли справа стосується почуття гордості, самоповаги, чоловічої гідності, патріотичного обов'язку та громадянської позиції. Однак, на практиці учасники емпіричного дослідження зрідка проявляли психоемоційне ставлення, оповідь швидше нагадувала констатацію фактів, що було демонстрацією зовнішнього патерну поведінки: витриманого, емоційно скутого, іноді вдавано індиферентного. Подібна манера спілкування свідчить про психоментальні особливості культури виховання хлопчика: заборона на автентичні емоції і почуття, іронічна критика проявустраху чи сорому. Такі характеристики свідчать про домінування у респондентів драйверної поведінки «Будь 
сильним», «Будь досконалим», що трактується у контексті теорії транзактного аналізу [Герасіна, Гуріна, 2017: с. 100].

Отже, результати емпіричного дослідження свідчать про доцільність і необхідність впровадження системи психотерапевтичної та реабілітаційної допомоги учасникам АТО.

Основна мета психотерапевтичної роботи полягає в тому, щоб максимально повно відновити попередній рівень соціального й особистісного функціонування потерпілих. При цьому психотерапія спрямовується на:

- створення нової когнітивної моделі життєдіяльності;

- афективну переоцінку травматичного досвіду;

- відновлення відчуття цінності власної особистості;

- відновлення здатності подальшого існування у світі.

На думку О. Чабана, при проведенні психотерапії варто орієнтуватися на такі основні принципи: обов'язковість психотерапевтичного втручання; максимально ранній початок після психотравми з метою запобігання розвитку і хронізації ПТСР; комплексне тривале психотерапевтичне втручання у поєднанні 3 фармакотерапією. У контексті розглянутої проблематики при виборі форми проведення психотерапіїперевага надається не індивідуальній чи груповій, акомплексному поєднаннюпсихотерапевтичних заходів, які сприятимуть більш конструктивному підходу до роботи 3 психічними проявами постраждалих.

Серед основних психотерапевтичних стратегій науковці вказують на необхідність [Близнюк, 2015; Попіль, 2016; Підлисецька 2014]:

1. Підтримки адаптивних навичок «Я». 3 цією метою найчастіше використовуються такі психокорекційні техніки: систематична десенсибілізація; тренінги релаксації; зменшення зовнішніх вимог; техніки відновлення ресурсів власного «Я».

2. Формування «позитивного ставлення» до симптому. Оскільки люди, які страждають на ПТСР, пережили події, що виходять за рамки звичайного людського досвіду, то в них виникають незрозумілі та важкі для них переживання i реакції. Психокорекція спрямована на те, щоб допомогти клієнтам зрозуміти, що їхні реакції нормальні, а пережите екстремальне. Це дає змогу запобігти подальшій травматизації людини вже самими хворобливими симптомами, а також актуалізувати власні особистісні ресурси.

3. Зменшення уникання. Як відомо, для пацієнтів із ПТСР характерне завзяте уникання зіткнення з усім, що пов'язано 3 травмою. Уникання відбувається на декількох рівнях: уникання емоцій, спогадів, поведінкове i когнітивне уникання. У зв'язку 3 наявністю уникання травматичний досвід не трансформується, продовжує залишатися хворобливим, процес уникання є додатковою проблемою, що водночас замасковує і загострює ситуацію. 


\section{Psychology}

4. Зміна атрибуції змісту. Домінантою є зміна змісту, що надається травматичній ситуації та іiі наслідкам. Необхідною умовою ефективного відновлення $\epsilon$ формування відчуття «контролю за травмою». Багато авторів розглядають це відчуття як загальну кінцеву мету, до якої повинні прагнути всі психотерапевтичні інтервенції,цілі якої значною мірою визначаються як актуальними переживаннями бійця, так і динамікою ПТСР. Зазначимо, що найбільша кількість відмовлянь від психотерапевтичних інтервенцій спостерігається саме серед клієнтів із ПТСР. До визначеного моменту вони не усвідомлюють своєї проблеми, не вважають себе психотравмованими і потрапляють у поле зору фахівців, як правило, із приводу коморбідних розладів (психосоматичних порушень, депресії, аутоагресивної поведінки, адикційтощо).

Висновки. У результаті теоретико-емпіричного дослідження діагностовано особливості психоемоційного стану військовослужбовців; виявлено специфіку прояву ПТСР в учасників бойових дій, які перебували у зоні АТО; обгрунтованоосновні стресогенні фактори, що посилюють психотравматизацію та соціальну дезадаптацію бійця.

Так, у ході теоретичного аналізу з'ясовано, що сучасні бойові дії супроводжуються підвищеним стресогенним впливом на психіку бійців: тривале перебування у зоні війни; вплив надмірних фізичних навантажень; емоційно-вольове та мотиваційне перенапруження; порушення біоритму життєдіяльності тощо, спричиняє психофізіологічне виснаження та дистрес, що негативно відображається на психоемоційному стані бійців та провокує розвиток надмірної тривожності,невротичних станів та депресії. Стрес, пережитий людиною в екстремальних ситуаціях, як правило, за своєю інтенсивністю виходить за межі звичайного людського досвіду, що часто провокує різні психічні розлади. Спектр можливих психічних розладів, пов'язаних 3 переживанням життєво небезпечних ситуацій, містить гостру реакцію на стрес, ПТСР, розлади адаптації, гострі i транзиторні психотичні розлади, депресивні і тривожні розлади, хронічні зміни особистості. Вказані порушення є причиноюінтрузивних спогадів та переживань, «випадання» людини із повсякденності, фіксації на травмі, що спричиняє погіршення якості життя та уміння пристосовуватися, а в результаті - до розвитку ПТСР.

\section{ЛІТЕРАТУРА}

Агаєв, 2016 - Агаєв Н. А. Збірник методик для діагностики негативних психічних станів військовослужбовців: [метод. посібн.] / Н. А. Агаєв, О. М. Кокун, І. О. Пішко, Н. С. Лозінська, В. В. Остапчук. - К. : НДЦ ГП ЗСУ, 2016. - 234 с.

Близнюк, 2015 - Близнюк А.И. Посттравматическое стрессовое расстройство (ПТСР) у комбатантов, клиника, диагностика, коррекция / А. И. Близнюк // Военно-медицинский журнал. - Минск : БГМУ, 2015. - С. 1-15. [Інтернет ресурс]. Режим доступу : http://docplayer.ru/ Posttravmaticheskoe-stressovoe-rasstroystvo-ptsr-u-kombatantov-klinika

Герасіна, 2017 - Герасіна С. В. Практичний досвід психологічної реабілітації учасників АТО у рекреаційно-оздоровчому центрі міста Хирів / С. В. Герасіна, 3. В. Гуріна // Актуальні проблеми психології: [3б. наук. пр. Ін-ту психології імені Г. С. Костюка НАПН 
України]. - Том. XI: Психологія особистості. Психологічна допомога особистості. 2017. - Вип. 15. - С. 90-102.

Волошин, 2016 - Діагностика, терапія та профілактика медико-психологічних наслідків бойових дій в сучасних умовах: [метод. реком. / укл. П. В. Волошин, Н. О. Марута, Л. Ф. Шестопалова， I. В. Лінський, $\quad$ В. С. Підкоритов, I. І. Ліпатов, Ю. С. Бучок, В. І. Заворотний]. - Харків : ДУ Ін-т неврології, психіатрії та наркології НАМН України, 2014. $-67 \mathrm{c}$.

Исаева,2009 - Исаева Е. Р. Копинг-поведение и психологическая защита личности в условиях здоровья и болезни / Е. Р. Исаева. - СПб. : ГМУ, 2009. - 136 с.

Імплементація сучасних технологій, 2016 - Науково-практична конференція: «Імплементація сучасних технологій відновного лікування постраждалих в умовах особливого періоду» / Громадська організація: Асоціація з медичної та психологічної реабілітації: [програма заходу]. - 9 грудня 2016. - К., 2016. -12 с.

Підлисецька, 2014 - Підлисецька Л. Б. Посттравматичний стресовий розлад. Синопсис діагностичних критеріїв для діагностики та лікування основних психічних розладів Л. Б. Підлисецька. - 2014. - 112 с.

Попіль, 2016 - Попіль М. І. Психологічна допомога у кризових та екстремальних ситуаціях / М. І. Попіль - Дрогобич : Редакційно-видавничий відділ ДДПУ ім. Івана Франка, 2016. $-135 \mathrm{c}$

Рыбников, 2012 - Рыбников В. Ю. Психология копинг-поведения специалистов опасных профессий / В. Ю. Рыбников, Е.Н.Ашанина // Монография. - СПб. : ПолитехникаСервис, 2012. -120 c.

Тарабрина, 2009 - Психология посттравматического стресса / Н. В. Тарабрина. - Институт психологии РАН. - 2009. - 304 с. [Інтернет ресурс] / Режим доступу : http://lifeinbooks.net/chto-pochitat/psihologiya-posttravmaticheskogo-stressa-nadezhdatarabrina/

\section{REFERENCES}

Ahaiev, 2016 - Ahaiev N. A. Zbirnyk metodyk dlia diahnostyky nehatyvnykh psykhichnykh staniv viiskovosluzhbovtsiv: [metod. posibn.] / N. A. Ahaiev, O. M. Kokun, I. O. Pishko, N. S. Lozinska, V. V. Ostapchuk. - K. : NDTs HP ZSU, 2016. - 234 s.

Bliznyuk, 2015 - Bliznyuk A. I. Posttravmaticheskoe stressovoe rasstroystvo (PTSR) u kombatantov, klinika, diagnostika, korrektsiya / A. I. Bliznyuk // Voenno-meditsinskiy zhurnal. - Minsk : BGMU. - 2015. - S. 1-15. [Internet resurs]. - Rezhim dostupu http://docplayer.ru/Posttravmaticheskoe-stressovoe-rasstroystvo-ptsr-u-kombatantov-klinika

Herasina, 2017 - Herasina S. V. Praktychnyi dosvid psykholohichnoi reabilitatsii uchasnykiv ATO u rekreatsiino-ozdorovchomu tsentri mista Khyriv / S. V. Herasina, Z. V. Hurina // Aktualni problemy psykholohii: [zb. nauk. pr. In-tu psykholohii imeni H. S. Kostiuka NAPN Ukrainy]. - Tom. KhI: Psykholohiia osobystosti. Psykholohichna dopomoha osobystosti. - 2017. Vyp. 15. - S. 90-102.

Isaeva, 2009 - Isaeva E. R. Koping-povedenie i psihologicheskaya zaschita lichnosti v usloviyah zdorovya i bolezni / E. R. Isaeva. - SPb. : GMU, 2009. - 136 c.

Voloshyn, 2016 - Diahnostyka, terapiia ta profilaktyka medyko-psykholohichnykh naslidkiv boiovykh dii v suchasnykh umovakh: [metod. rekom. / ukl. P. V. Voloshyn, N. O. Maruta, L. F. Shestopalova, I. V. Linskyi, V. S. Pidkorytov, I. I. Lipatov, Yu. S. Buchok, V. I. Zavorotnyi]. - Kharkiv : DU In-t nevrolohii, psykhiatrii ta narkolohii NAMN Ukrainy, 2014. $-67 \mathrm{~s}$

Implementatsiia suchasnykh tekhnolohii, 2016 - Naukovo-praktychna konferentsiia: «Implementatsiia suchasnykh tekhnolohii vidnovnoho likuvannia postrazhdalykh $\mathrm{v}$ umovakh osoblyvoho periodu» / Hromadska orhanizatsiia: Asotsiatsiia z medychnoi ta psykholohichnoi reabilitatsii: [prohrama zakhodu]. -9 hrudnia 2016. - K., 2016. - $12 \mathrm{~s}$.

Pidlysetska, 2014 - Pidlysetska L. B. Posttravmatychnyi stresovyi rozlad. Synopsys diahnostychnykh kryteriiv dlia diahnostyky ta likuvannia osnovnykh psykhichnykh rozladiv / L. B. Pidlysetska. $-2014 .-112 \mathrm{~s}$. 


\section{Psychology}

Popil, 2016 - Popil M. I. Psykholohichna dopomoha u kryzovykh ta ekstremalnykh sytuatsiiakh / M. I. Popil - Drohobych, Redaktsiino-vydavnychyi viddil DDPU im. Ivana Franka, 2016. $135 \mathrm{~s}$.

Ryibnikov, 2012 - Ryibnikov V. Yu. Psihologiya koping-povedeniya spetsialistov opasnyih professiy /

V. Yu. Ryibnikov, E. N. Ashanina. - SPb. : Politehnika-Servis, 2012. - 120 s.

Tarabrina, 2009 - Psihologiya posttravmaticheskogo stressa / N. V. Tarabrina. - Institut psihologii RAN. - 2009. - 304 s. [Internet resurs]. - Rezhim dostupu : http://lifeinbooks.net/chtopochitat/psihologiya-posttravmaticheskogo-stressa-nadezhda-tarabrina.

\section{УДК 159.928}

\section{Ірина Гречуха}

\section{ПСИХОСОЦІАЛЬН ЧИННИКИ РОЗВИТКУ ЛІТЕРАТУРНО ОБДАРОВАНОЇ ОСОБИСТОСТІ}

Статтю присвячено аналізу психосочіальних чинників розвитку літературно обдарованої особистості. Описано особливості впливу референтних осіб на розвиток літературно обдарованої особистості школяра у різні вікові періоди. Доведено, щзо наявність у сочиіальному оточенні дитини значущиих для неї людей, які є взіриями та підтримують ї̈ на всіх етапах творчого розвитку, є однією з умов особистісного зростання. Зазначено, щяо важливим мотивувальним чинником розвитку літературних здібностей, особливо на початкових етапах, $\epsilon$ задоволення потреби у визнанні та поцінуванні.Емпіричним иляхом встановлено, щзо на всіх етапах становлення літературно обдарованої особистості особливу роль відіграють учитель украӥнської мови ц̌ літератури та віртуальні референтні особи (письменники, поети, драматурги), які $\epsilon$ для учнів стандартами літературної творчості та майстерності.Встановлено співвідношення віртуальних $i$ реальних осіб у структурі референтності старшокласників.

Ключові слова: сочіальна ситуаџія розвитку, обдарована особистість, вікова обдарованість, ознаки обдарованості, літературно обдарована особистість, життєвий шлях, біографічна бесіда, референтні особи.

The article is devoted to the analysis of the psychosocial factors of development of a literary gifted personality.The article reveals the essence of such psychological categories as: "gifted personality», "age-related giftedness», «signs of giftedness» and «literary gifted personality». The diagnostic features of the biographical interview, as a method of examining of literary gifted personality have been analyzed. While exploring the life path of a person, we see its reflection in the events, circumstances and social environment in which the individual grew up and developed. The features of the influence of reference persons on the development of a literary-gifted pupil s personality in various age periods are described.It has been proved that the presenceof significant people in the social environment of the child, who are his inheritance examples and support him at all stages of his creative development, is a condition for personal growth.It has been noted that an important motivating factor for the development of literary abilities, especially in the initial stages, is a meeting the need for acknowledgment and recognition.

The age dynamics in the reference structure of literary gifted personalities consists in its expansion and complication: preschool age - orientation toward supporting the immediate environment (family and relatives), junior school age - expanding the circle of reference persons (adding friends, classmates, and school teachers); adolescence - displacement of the reference dominance to friends and classmates, to the teacher of the Ukrainian language and literature and the head of the literary club, as well as appearing of virtual reference persons; early adolescence - increasing of the reference rate of virtual persons, the high level of reference of friends, the teacher of the Ukrainian language and literature and the head of the literary club remains the same. Empirically, it has been established that at all stages of the development of a literary gifted personality, a special role is played by the teacher of the Ukrainian language and literature and virtual reference persons (writers, poets, playwrights) who are standards of literary creativity and skill forpupils. 